\title{
DETERMINANTRANSPARANSIINFORMASIKEUANGANDAERAHMELALUI E-GOVERNMENTPEMERINTAHDAERAHDISUMATERASELATAN
}

\author{
Verawaty \\ Universitas Bina Darma \\ verawaty_mahyudin@yahoo.com
}

\begin{abstract}
The purposeofthis study was to analyze the association of Local Own Source Revenue, General Allocation Fund, Special Allocation Fund, and Debt Ratio as the determinants of the Local Government Financial Information Transparency. The population was all local government in South Sumatra. The statistical results showed that only Local Own Source Revenue showed the positive associationto Financial Information Transparency. The study implication recommends that the local government must improve the implementation of e-governmentin order to enhance accounting transparency that they present in the website.
\end{abstract}

Keywords: Local Own Source Revenue, General Allocation Fund,Special Allocation Fund, Debt Ratio, Local Government Financial Information Transparency

AKUISISI : Jurnal Akuntansi dan Keuangan

Website : http://www.fe.ummetro.ac.id/ejournal/index.php/JA

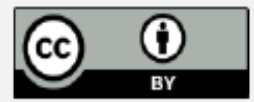

This is an open access article distributed under the terms of the Creative Commons Attribution 4.0 International License, which permits unrestricted use, distribution, and reproduction in any medium, provided the original work is properly cited.

\section{PENDAHULUAN}

Fenomena yang terjadi dalam perkembangan akuntansi sektor publik di Indonesia saat ini adalah semakin menguatnya tuntutan transparansi publik oleh masyarakat, baik pusat maupun daerah. Berdasarkan dimensi transparansi publik berdasarkan Solihin (2006), yaitu akses kebebasan bagi setiap orang untuk memperoleh informasi tentang penyelenggaraan pemerintah dan berbagai kebijakan publik dan yang menyangkut proses penyusunan dan pelaksanaan, serta hasil-hasilnya yang dicapai. Menurut Verawaty (2017), bila dikaitkan dengan e-government, khususnya untuk aspek akuntansi sektor publik, konsep transparansi sangat penting. Publik berhak mengetahui alokasi dana publik, bahkan mulai dari perencanaan, pengimplementasian dan progresnya, pelaporannya, dan hasil pengauditannya oleh BPK. Media e-government dapat menjadi sarana publikasi kinerja keuangan yang merefleksikan penyelenggaraan pemerintahan yang menyangkut pengelolaan sumber daya publik. 
Peningkatan transparansi dapat dilihat dari ketersediaan suatu informasi dan aksesibilitasnya dalam memperoleh informasi tersebut untuk publik, maka salah satu cara yang paling efektif dalam melaksanakan keterbukaaninformasi keuangan publik adalah menggunakan media elektronik yaitu situsresmi yang dalam istilah sistem informasi untuk pemerintahan disebut e-government. Kravchuk dan Voorhees (1999); Mead (2002); Styles dan Tennyson (2007); Verawaty (2017) menyetujui bahwa bahwa penyebaran laporan ini merupakan tanggung jawab dan dikendalikan oleh pemerintah daerah. Tentunya salah satu cara yang paling efektif dari segi cara, efisien dari segi waktu, dan ekonomis dari segi biaya untuk agen pemerintah yang diotorisasi untuk tanggung jawab tersebut untuk menyebarkan informasi ini, internet dengan aplikasi IFR (Internet Financial Reporting) melalui e-government merupakan alternatif yang tepat.

Dalam penelitian ini, aspek yang akan dibahas yaitu, pendapatan asli daerah (PAD), dana alokasi umum (DAU), dana alokasi khusus (DAK), dan rasio pembiayaan hutang (RPH). Penelitian ini berbeda dengan penelitian yang telah dilakukan sebelumnya. Peneliti menambahkan variabel DAK karena variabel ini juga menjadi tolak ukur untuk menilai pengungkapan transparansi informasi keuangan pemerintah daerah sehingga mampu meningkatkan kepercayaan masyarakat terhadap pemerintah daerah dalam menjalankan tata kelola pemerintah yang baik.

Penelitian acuan, Pitri dan Merina (2017) hanya memiliki nilai koefisien determinasi sebesar 0,551. Artinya hanya 55,1\% variabel pengungkapan transparansi informasi keuangan pemerintah daerah dapat diterangkan dengan variabel determinan. Sisanya sekitar 44,9\% dipengaruhi oleh faktor lain yang tidak diamati dalam penelitian tersebut. Selain itu nilai tersebut berarti sebagian besar variabel yang digunakan tidak terbukti mempunyai pengaruh positif dengan pengungkapan transparansi informasi keuangan pemerintah daerah sehingga peneliti mengurangi jumlah variabel dari penelitian acuan dan menambah satu variabel baru.

Penelitian-penelitian terdahulu lainnya yang membahas mengenai faktor-faktor yang mempengaruhi transparansi informasi keuangan pada situs resmi pemerintah daerah antara lain Laswad dkk (2005); Styles dan Tennyson (2007); Hilmi (2010); Lesmana (2010); Rora (2010); Syafitri (2012); Medina (2012); Jeckly dan Eka (2014); Verawaty (2015); Nainggolan dan Purwanti (2016); Verawaty (2017); Pitri dan Merina (2017) pun masih memberikan hasil yang berbedaberbeda mengenai determinan transparansi informasi keuangan pemerintah daerah. Penelitian ini akan memberikan rekomendasi sebagai bahan pertimbangan bagi pemerintah daerah di Sumatera Selatan dalam upaya meningkatkan penerapan e-government dalam bidang akuntansi, yaitu IFR (Internet Financial Reporting) sehingga akan tercapai transparansi publik yang semestinya. 


\section{DeterminanTransparansiInformasi}

\section{TINJAUAN PUSTAKA}

\section{Teori Agensi dan Teori Sinyal (Signalling Theory) dalam Pemerintahan}

Menurut Zimmerman (1976) dalam Verawaty (2017), agency problem juga ada dalam konteks organisasi pemerintahan. Rakyat sebagai prinsipal memberikan mandat kepada pemerintah sebagai agen, untuk menjalankan tugas pemerintahan dalam rangka meningkatkan kesejahteraan rakyat. Dalam konteks lain, politisi dapat juga disebut prinsipal karena menggantikan peran rakyat. Namun dapat juga dipandang sebagai agen karena menjalankan tugas pengawasan yang diberikan oleh rakyat. Implikasi dari teori ini, prinsipal, yaitu rakyat secara langsung perlu melakukan pengawasan kepada agen, baik pemerintah maupun para politisi. Politisi sebagai prinsipal juga memerlukan informasi untuk mengevaluasi jalannya pemerintah.

Hubungan prinsipal dan agen dapat dilihat dalam politik demokrasi (Moe, 1984 dalam Verawaty, 2017). Masyarakat adalah prinsipal, politisi (legislatif) adalah agen mereka. Politisi (legislatif) adalah prinsipal, birokrat/pemerintah adalah agen mereka. Pejabat pemerintahan adalah prinsipal, pegawai pemerintahan adalah agen mereka. Keseluruhan politik tersusun dari alur hubungan prinsipal-agen, dari masyarakat hingga level terendah pemerintahan. Fadzil dan Nyoto (2011) juga menyatakan bahwa terdapat hubungan prinsipal-agen antara pemerintah pusat dan pemerintah daerah. Pemerintah pusat adalah prinsipal dan pemerintah daerah bertindak sebagai agen. Hal ini dikarenakan, Indonesia sebagai negara kesatuan, pemerintah daerah bertanggung jawab kepada masyarakat sebagai pemilih dan juga kepada pemerintah pusat.

Dalam konteks teori signalling, pemerintah berusaha untuk memberikan sinyal yang baik kepada rakyat (Evans dan Patton, 1987 dalam Verawaty, 2017). Tujuannya agar rakyat dapat terus mendukung pemerintah yang saat ini berjalan sehingga pemerintahan dapat berjalan dengan baik. Laporan keuangan dapat dijadikan sarana untuk memberikan sinyal kepada rakyat. Kinerja pemerintahan yang baik perlu diinformasikan kepada rakyat baik sebagai bentuk pertanggungjawaban maupun sebagai bentuk promosiuntuk tujuan politik.

Jika dikaitkan dengan penelitian ini, pemerintah bertanggung jawab memberikan informasi atau sinyal pada masyarakat untuk memberikan keyakinan yang memadai pada masyarakat. Tujuannya agar rakyat dapat terus mendukung pemerintah yang saat ini berjalan sehingga pemerintahan dapat berjalan dengan baik. Tentu dengan diseminasi melalui keunggulan internet dengan fasilitas e-government seperti ini dapat didistribusikan lebih cepat dan dapat dieksploitasi untuk lebih membuka diri atau transparan dengan menginformasikan laporan keuangannya. 


\section{Penelitian-Penelitian Terdahulu dan Pengembangan Hipotesis}

\section{Pengaruh Pendapatan Asli Daerah terhadap Transparansi Informasi Keuangan Daerah}

Berdasarkan UU No. 32 Tahun 2004, salah satu sumber pendapatan daerah adalah pendapatan asli daerah yang terdiri dari hasil pajak daerah, hasil retribusi daerah, hasil pengelolaan kekayaan daerah yang dipisahkan dan lain-lain pemerintah asli daerah yang sah. Craven dan Marston (1999) menunjukkan bahwa pemerintah daerah yang buruk akan menghindari pengungkapan sukarela seperti voluntary internet based disclosure dan akan memilih membatasi pengungkapan informasi bagi masyarakat.

Pendapatan asli daerah (PAD) merupakan wujud kemandirian dalam memperoleh pendapatan sehingga dapat digunakan untuk memenuhi kebutuhan daerah dengan menggunakan mekanisme APBD. Rora (2010), Nainggolan dan Purwanti (2016) serta Pitri dan Merina (2017), menyebutkan bahwa PAD tidak berpengaruh terhadap pengungkapan ataupun ketersediaan konten pemerintah daerah, sedangkan Jeckly dan Eka (2014) yang meneliti tingkat PAD menyatakan bahwa PAD berpengaruh positif terhadap transparansi informasi keuangan daerah. Dalam hal ini pemerintah daerah sudah cenderung memberikan kemudahan dan kenyamanan dalam mengakses. Dari penelitian terdahulu, masih adanya temuan hasil penelitian yang tidak konsisten sehingga peneliti perlu melakukan pengujian kembali untuk mengetahui temuan penelitian transparansi informasi keuangan ke dalam hipotesis sebagai berikut:

$\mathrm{H}_{1}$ : Pendapatan asli daerah berpengaruh positif terhadap transparansi informasi keuangan daerah

\section{Pengaruh Dana Alokasi Umum terhadap Transparansi Informasi Keuangan Daerah}

Jumlah Dana Alokasi Umum (DAU) bagi semua daerah provinsi dan jumlah DAU bagi semua daerah kabupaten/kota masing-masing ditetapkan setiap tahun dalam APBN. DAU untuk suatu daerah kabupaten/kota tertentu ditetapkan berdasarkan jumlah DAU untuk suatu daerah kabupaten/kota yang ditetapkan dalam APBN dikalikan dengan rasio bobot daerah kabupaten/kota tersebut, terhadap jumlah bobot seluruh kabupaten/kota. Porsi daerah kabupaten/kota ini merupakan persentase bobot daerah kabupaten/kota yang bersangkutan terhadap jumlah bobot semua daerah kabupaten/kota.

Berdasarkan Undang-Undang No. 33 Tahun 2004, DAK adalah dana yang berasal dari APBN yang dialokasikan dengan tujuan pemerataan keuangan antar daerah untuk membiayai kebutuhan pengeluaran dalam rangka pelaksanaan desentralisasi. Berdasarkan Jeckly dan Eka (2014) serta Pitri dan Merina (2017), DAU tidak berpengaruh terhadap transparansi informasi keuangan daerah, sedangkan menurut Liestiani (2008) dan Syafitri (2012), variabel DAU berpengaruh terhadap transparansi informasi keuangan daerah karena dengan adanya DAU dari 


\section{DeterminanTransparansiInformasi}

pemerintah pusat maka pemerintah daerah bisa mengalokasikan pendapatannya untuk membiayai transparansi informasi keuangan daerah. Berdasarkan uraian di atas maka dirumuskan hipotesis penelitian sebagai berikut:

\section{$\mathrm{H}_{2}$ : $\quad$ Dana alokasi umum berpengaruh positif terhadap transparansi informasi keuangan daerah}

\section{Pengaruh Dana Alokasi Khusus terhadap Transparansi Informasi Keuangan Daerah}

Berdasarkan Undang-undang No. 33 Tahun 2004, Dana Alokasi Khusus (DAK) merupakan dana yang bersumber dari APBN yang dialokasikan kepada daerah tertentu dengan tujuan untuk membantu mendanai kegiatan khusus yang merupakan urusan daerah dan sesuai dengan prioritas nasional. Menurut Ardhani (2011), DAK merupakan dana yang bersumber dari APBN yang dialokasikan kepada pemerintah daerah untuk membiayai kegiatan khusus yang merupakan urusan daerah dan prioritas nasional. Tujuan DAK untuk mengurangi beban dan biaya kegiatan khusus yang harus ditanggung oleh pemerintah daerah. Pemanfaatan DAK diarahkan kepada kegiatan investasi pembangunan, pengadaan, peningkatan, perbaikan sarana dan prasarana fisik pelayanan publik dengan umur ekonomis panjang agar diharapkan dapat meningkatkan pelayanan publik.

Berdasarkan Jeckly dan Eka (2014), DAU tidak berpengaruh terhadap transparansi informasi keuangan daerah, maka diharapkan dana perimbangan lainnya, yaitu DAK akan mempengaruhi karena dengan adanya DAK dari pemerintah pusat maka pemerintah daerah bisa mengalokasikan pendapatannya untuk membiayai transparansi informasi keuangan daerah. Berdasarkan uraian di atas maka dirumuskan hipotesis penelitian sebagai berikut:

\section{$\mathrm{H}_{3}$ : Dana alokasi khusus berpengaruh positif terhadap transparansi informasi keuangan daerah}

\section{Pengaruh Rasio Pembiayaan Hutang terhadap Transparansi Informasi Keuangan Daerah}

MenurutStyles dan Tennyson (2007), berpendapat bahwa dengan melakukan pembiayaan terhadap pengeluaran-pengeluaran pemerintah saat ini akan memberikan dampak pada kemampuan pemerintah daerah memberikan pelayanan dan program terpadu bagi masyarakat di masa yang akan datang. Namun besarnya hutang tidak boleh melebihi jumlah dari modal yang dimiliki. Menurut Zimmerman (1977) dan Ingram (1984) dalam Gore (2004) dan Verawaty (2017), pengungkapan informasi keuangan melalui internet dapat memfasilitasi kreditur untuk mengawasi kinerja pemerintah.

Syafitri (2012), dalam sektor swasta, laporan keuangan digunakan oleh kreditur sebagai alat untuk menilai kemampuan organisasi dalam membayar kewajibannya di masa yang telah ditentukan. Oleh karena itu kreditur sering kali menghendaki pengungkapan yang lengkap pada laporan keuangan. Begitu halnya dengan pemerintah pihak kreditur akan menuntut pengungkapan

yang lebih besar sebagai bentuk pertanggungjawaban transparansi dan akuntabilitas atas 
pembiayaan yang telah diberikan kreditur. Medina (2012), Verawaty (2015) dan Nainggolan dan Purwanti (2016) serta Pitri dan Merina (2017), tidak menemukan hubungan positif antara rasio pembiyaan hutang (RPH) dengan transparansi informasi keuangan pemerintah daerah. Namun menurut Laswad dkk (2005) dan Rora (2012), sebaliknya menyatakan bahwa RPH berpengaruh terhadap transparansi informasi keuangan daerah sehingga peneliti perlu melakukan pengujian kembali untuk mengetahui temuan penelitian transparansi informasi keuangan ke dalam hipotesis sebagai berikut:

$\mathrm{H}_{4}$ : $\quad$ Rasio pembiayaan hutang berpengaruh positif terhadap transparansi informasi keuangan daerah

\section{METODOLOGI PENELITIAN}

\section{Operasional Variabel}

\begin{tabular}{|c|c|c|c|}
\hline Variabel & Definisi & Indikator & $\begin{array}{l}\text { Skala } \\
\text { Ukur }\end{array}$ \\
\hline $\begin{array}{l}\text { Variabel Independen: } \\
\text { 1. Pendapatan Asli } \\
\text { Daerah (PAD) } \\
\text { (X1) }\end{array}$ & $\begin{array}{l}\text { Pendapatan asli daerah merupakan } \\
\text { sumber penerimaan daerah asli yang } \\
\text { digali di daerah tersebut untuk } \\
\text { digunakan sebagai modal dasar } \\
\text { pemerintah daerah dalam membiayai } \\
\text { pembangunan dan usaha-usaha } \\
\text { daerah untuk memper kecil } \\
\text { ketergantungan dana dari pemerintah } \\
\text { pusat yang terdiri dari pajak daerah, } \\
\text { retribusi daerah, hasil pengelolaan } \\
\text { kekayaan daerah yang dipisahkan, } \\
\text { dan lain-lain pendapatan daerah yang } \\
\text { sah. }\end{array}$ & $\begin{array}{l}\text { Realisasi } \\
\text { Pendapatan Asli } \\
\text { Daerah (PAD) }\end{array}$ & Nominal \\
\hline $\begin{array}{l}\text { 2. Dana Alokasi } \\
\text { Umum } \\
\text { (X2) }\end{array}$ & $\begin{array}{l}\text { Dana alokasi umum merupakan salah } \\
\text { satu transfer dana pemerintah kepada } \\
\text { pemerintah daerah yang bersumber } \\
\text { dari pendapatan APBN dengan } \\
\text { tujuan pemerataan kemampuan } \\
\text { keuangan antardaerah }\end{array}$ & $\begin{array}{l}\text { Realisasi Dana } \\
\text { Alokasi Umum } \\
\text { (DAU) }\end{array}$ & Nominal \\
\hline $\begin{array}{lr}\text { 3. } & \text { Dana } \\
\text { Khusus } & \text { atau }\end{array}$ & $\begin{array}{l}\text { Dana alokasi khusus merupakan } \\
\text { salah satu transfer dana pemerintah }\end{array}$ & $\begin{array}{l}\text { Realisasi Dana } \\
\text { Alokasi Khusus }\end{array}$ & Nominal \\
\hline
\end{tabular}




\begin{tabular}{|c|c|}
\hline DAK (X3) & $\begin{array}{l}\text { kepada pemerintah daerah yang (DAK) } \\
\text { bersumber dari pendapatan APBN } \\
\text { yang dialokasikan kepada daerah } \\
\text { tertentu dengan tujuan untuk } \\
\text { membantu mendanai kegiatan khusus } \\
\text { yang merupakan urusan daerah dan } \\
\text { sesuai dengan prioritas nasional. }\end{array}$ \\
\hline $\begin{array}{l}\text { 4. Rasio } \\
\text { Pembiayaan } \\
\text { Hutang } \\
\text { (X4) }\end{array}$ & $\begin{array}{ll}\text { Rasio pembiayaan hutang merupakan } & \text { Total kewajiban } \\
\text { proporsi yang menggambarkan } & \text { dibandingkan } \\
\text { besarnya hutang dari pihak eksternal } & \text { dengan total } \\
\text { dibandingkan dengan modal sendiri. } & \text { ekuitas }\end{array}$ \\
\hline $\begin{array}{l}\text { Variabel Dependen: } \\
\text { Transparansi Informasi } \\
\text { keuangan (Y) }\end{array}$ & 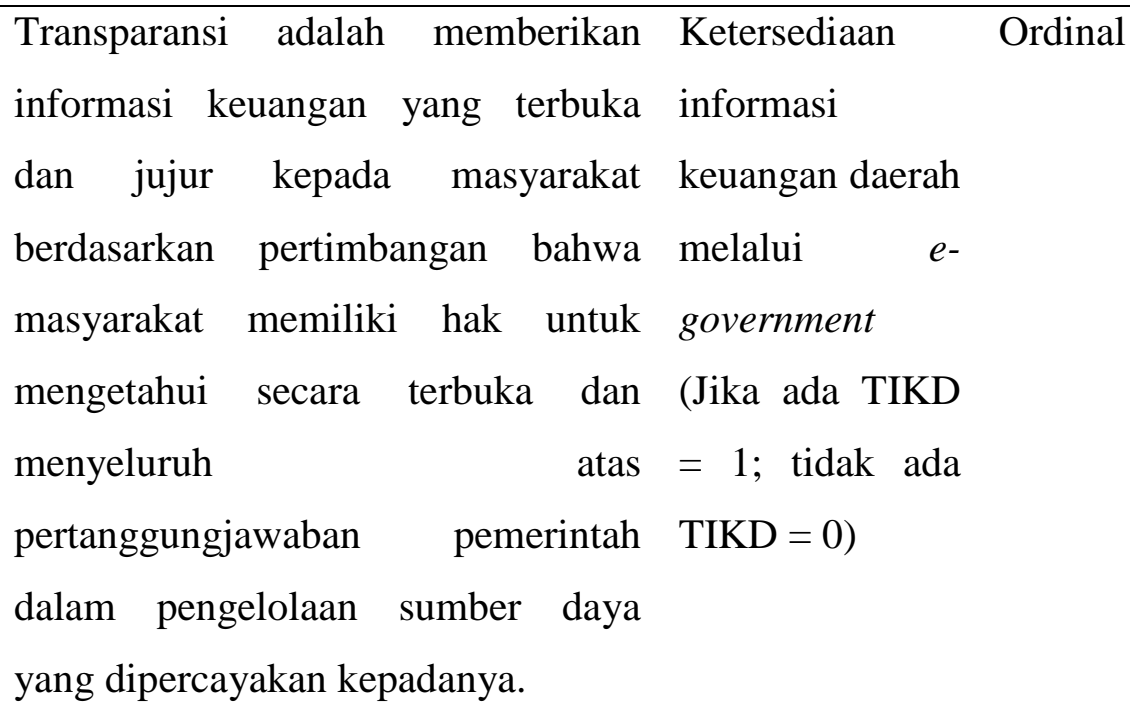 \\
\hline
\end{tabular}

\section{Populasi dan Sampel}

Populasi menurut Sugiyono (2012) merupakan wilayah generalisasi yang terdiri atas subjek atau objek yang mempunyai kuantitas dan karakteristik tertentu yang ditetapkan oleh peneliti untuk dipelajari dan kemudian ditarik kesimpulannya. Populasi dalam penelitian ini adalah pemerintah provinsi dan seluruh kabupaten/kota di Provinsi Sumatera Selatan tahun 2017.

\section{Teknik Analisis}

Untuk menguji hipotesis, penelitian ini menggunakan analisis regresi linier berganda. Persamaan regresi yang digunakan dalam penelitian ini adalah:

$\mathrm{TIKD}=\alpha+\beta_{1} \cdot \mathrm{PAD}+\beta_{2} \cdot \mathrm{DAU}+\beta_{3} \mathrm{DAK}+\beta_{4} \cdot \mathrm{RPU}+\mathrm{e}$ 
Keterangan:

$\alpha \quad$ : Konstanta

$\beta \quad$ : Koefisien Regresi

TIKD : Transparansi Informasi Keuangan Daerah

PAD : Pendapatan Asli Daerah

DAU : Dana Alokasi Umum

DAK : Dana Alokasi Khusus

RPU : Rasio Pembiayaan Hutang

e : Koefisien eror

HASIL DAN PEMBAHASAN

Hasil Penelitian

Uji Nilai Likelihood

Omnibus Tests of Model Coefficients

\begin{tabular}{lllll}
\hline & & Chi-square & df & Sig. \\
\hline Step 1 & Step & 11,551 & 4 &, 021 \\
\cline { 2 - 5 } & Block & 11,551 & 4 &, 021 \\
\cline { 2 - 5 } & Model & 11,551 & 4 &, 021
\end{tabular}

Omnibus test dilakukan untuk menilai apakah model secara keseluruhan cocok (fit) dengan data yang tersedia. Pada model ini diperoleh nilai sig 0,021 yang menunjukkan bahwa model yang dibentuk signifikan dan cocok dengan data.

Koefisien Determinasi (Negelkerke R Square)

Model Summary

\begin{tabular}{|c|c|c|c|}
\hline & -2 & Log Cox \& Snell & Nagelkerke $\mathrm{R}$ \\
\hline Step & likelihood & R Square & Square \\
\hline 1 & $13,180^{\mathrm{a}}$ & ,474 & 634 \\
\hline
\end{tabular}

a. Estimation terminated at iteration number 7 because parameter estimates changed by less than , 001 .

Koefisien determinasi adalah bagian dari variasi total dalam variabel dependen yang dijelaskan oleh variasi dalam variabel independen (variabilitas). Hal ini ditunjukkan dengan nilai $\mathrm{R}^{2}$. Penelitian ini memiliki nilai koefisien determinasi sebesar 0,634. Artinya hanya 63,4\% variabel pengungkapan transparansi informasi keuangan pemerintah daerah dapat diterangkan dengan 
DeterminanTransparansiInformasi

variabel bebas dalam penelitian ini. Sisanya sekitar 36,6\% dipengaruhi oleh faktor lain yang tidak diamati dalam penelitian ini.

Uji Nilai Hosmer and Lemeshow Test

\section{Hosmer and Lemeshow Test}

\begin{tabular}{llll}
\hline Step & Chi-square & df & Sig. \\
\hline 1 & 3,026 & 7 &, 883
\end{tabular}

Hosmer and lemeshow test digunakan untuk menilai kelayakan keseluruhan dari suatu model regresi. Suatu model dinyatakan layak jika memiliki nilai $\mathrm{p}>0,05$. Hasil nilai menunjukkan nilai sig 0,883 . Hal ini menunjukkan model sudah tepat dan mampu menjelaskan data yang ada.

\section{Menilai Akurasi Model}

\section{Classification Table ${ }^{\mathrm{a}}$}

\begin{tabular}{|c|c|c|c|c|c|}
\hline & \multirow{3}{*}{\multicolumn{2}{|c|}{ Observed }} & \multicolumn{3}{|l|}{ Predicted } \\
\hline & & & \multicolumn{2}{|l|}{ TIKD } & \multirow{2}{*}{$\begin{array}{l}\text { Percentage } \\
\text { Correct }\end{array}$} \\
\hline & & & Non IFR & IFR & \\
\hline \multirow[t]{4}{*}{ Step 1} & \multirow[t]{2}{*}{ TIKD } & Non IFR & 9 & 1 & 90,0 \\
\hline & & IFR & 2 & 6 & 75,0 \\
\hline & \multicolumn{4}{|c|}{ Overall } & \\
\hline & \multicolumn{4}{|c|}{ Percentage } & J \\
\hline
\end{tabular}

a. The cut value is, 500

Dari 10 pemerintah daerah yang tidak memiliki atau tidak ada pengungkapan informasi keuangan daerah, sebanyak 9 data $(90 \%)$ dapat diprediksi oleh model. Dari 8 pemerintah daerah yang ada mengungkapkan informasi keuangan daerah, hanya $6(75 \%)$ yang dapat diprediksi oleh model. Jika keberadaan pengungkapan informasi keuangan daerah dianggap sebagai variabel yang ingin diprediksi, maka dapat dikatakan sensitivitas model adalah 90\%. Secara keseluruhan akurasi model adalah $83,3 \%$. 
Model Regresi yang dihasilkan

Variables in the Equation

\begin{tabular}{llllllll}
\hline & B & S.E. & Wald & df & Sig. & Exp(B) \\
\hline Step 1 $^{\text {a }}$ & PAD & 8,260 & 4,877 & 2,869 & 1 &, 090 & 3866,142 \\
\cline { 2 - 7 } & DAU & $-11,307$ & 9,325 & 1,470 & 1 &, 225 &, 000 \\
\cline { 2 - 7 } & DAK & 2,173 & 6,083 &, 128 & 1 &, 721 & 8,783 \\
\cline { 2 - 7 } & RasioPembiyaanHu & & & & & 1775342422 \\
& & 42,021 & 30,327 & 1,920 & 1 &, 166 & 363296770,0 \\
& & & & & & 00 \\
\hline
\end{tabular}

a. Variable(s) entered on step 1: PAD, DAU, DAK, RasioPembiyaanUtang.

Hasil pemodelan regresi logistik yang ditampilkan dalam tabel di atas menunjukkan Nilai B koefisien dari setiap variabel bebas yang diuji. Sementara Nilai EXP (B) menunjukkan besar kemungkinan adanya pengungkapan informasi keuangan pada setiap pemerintah daerah. Setelah melakukan analisis regresi dari tabel di atas, maka nilai-nilai koefisien regresi tersebut dapat dimasukkan ke dalam persamaan regresi sebagai berikut:

TIKD $=15,757+8,260$ PAD $-11,307 \mathrm{DAU}+2,173 \mathrm{DAK}+42,021 \mathrm{RPU}+\mathrm{e}$

\section{Pembahasan}

Pendapatan Asli Daerah berpengaruh positif terhadap Transparansi Informasi Keuangan Daerah

Hasil penelitian ini membuktikan bahwa pendapatan asli daerah (PAD) berpengaruh positif terhadap transparansi informasi keuangan daerah. PAD memiliki koefisien regresi 8,260 dan nilai signifikansi 0,090 dimana nilai tersebut lebih besar dari $0,10(\alpha=10 \%)$. Hasil analisis tersebut konsisten dengan Jeckly dan Eka (2014) yang menyatakan PAD memiliki pengaruh terhadap transparansi informasi keuangan daerah. Akan tetapi, hasil analisis ini tidak konsisten dengan Rora (2012), Nainggolan dan Purwanti (2016) serta Pitri dan Merina (2017) yang menyatakan bahwa PAD tidak memiliki pengaruh terhadap transparansi informasi keuangan daerah.

Berdasarkan pengujian pertama yang telah dilakukan membuktikan bahwa semakin tinggi PAD maka pengungkapan transparansi informasi keuangan daerah akan semakin besar. PAD merupakan sumber penerimaan daerah asli yang digali di daerah tersebut digunakan sebagai modal dasar pemerintah daerah dalam membiayai pembangunan dan usaha-usaha daerah untuk memperkecil ketergantungan dana dari pemerintah pusat yang terdiri dari pajak daerah, retribusi 


\section{DeterminanTransparansiInformasi}

daerah, hasil pengelolaan kekayaan daerah yang dipisahkan, dan lain-lain pendapatan daerah yang sah, agar pemerintah daerah tidak cenderung berlomba-lomba mengeksploitasi PAD dengan membuat syarat pungutan baru yang dapat membebani masyarakat.

Dari hasil ini dapat disimpulkan bahwa PAD yang bersumber dari pajak dan retribusi yang dibayarkan oleh masyarakat bisa memotivasi pemerintah untuk dapat melakukan pengungkapan yang sesuai dengan Standar Akuntansi Pemerintahan (SAP). Masyarakat saat ini sudah memahami konsep hak dan kewajiban sebagai warga negara, yaitu melaksanakan kewajiban dan juga menuntut hak yang dalam hal ini adalah hak untuk mendapatkan informasi publik berupa informasi keuangan. Peran pemerintah (agen) dan masyarakat (partisipan) telah dapat terlaksana dengan baik. Selain itu, tingkat ketergantungan pemerintah daerah atas dana transfer semakin rendah sehingga menyebabkan pengungkapan PAD menjadi prioritas utama pemerintah daerah dalam pengungkapan transparansi informasi keuangan daerah. Jadi, hasil analisis ini menerima hipotesis bahwa PAD berpengaruh positif terhadap transparansi informasi keuangan daerah. Dengan demikian PAD dapat dijadikan determinan dalam menentukan transparansi informasi keuangan daerah melaluiegovernmentpemerintahdaerahdiSumateraSelatan.

\section{Dana Alokasi Umum berpengaruh positif terhadap Transparansi Informasi Keuangan Daerah}

Hasil penelitian ini membuktikan bahwa dana alokasi umum (DAU) tidak berpengaruh positif terhadap transparansi informasi keuangan daerah dengan nilai koefisien regresi -11,307 dan nilai signifikansi 0,225 dimana nilai tersebut lebih besar dari $0,10(\alpha=10 \%)$ dan $0,05(\alpha=5 \%)$. Hasil analisis tersebut tidak konsisten dengan Syafitri (2012) dan Liestiani (2008) yang menyatakan bahwa DAU memiliki pengaruh terhadap transparansi informasi keuangan daerah. Akan tetapi, hasil analisis ini konsisten dengan Jeckly dan Eka (2014) serta Pitri dan Merina (2017) yang menyatakan DAU tidak memiliki pengaruh terhadap transparansi informasi keuangan daerah.

Berdasarkan pengujian yang telah dilakukan tidak membuktikan bahwa DAU berpengaruh terhadap pengungkapan transparansi informasi keuangan daerah. DAU adalah dana yang dialokasikan kepada pemerintah daerah yang bertujuan pemerataan kemampuan keuangan antar daerah. DAU bersifat “Block Grant” yang artinya kepala daerah dapat menggunakan DAU sesuai kebutuhan suatu daerah yang diprioritaskan secara bertanggung jawab. Jumlah DAU bagi semua daerah khususnya kabupaten/kota masing-masing ditetapkan setiap tahun dalam APBD. Besaran DAU ditetapkan sekurang-kurangnya $26 \%$ dari pendapatan dalam negeri (PDN) Netto yang ditetapkan dalam APBN.

Dari hasil ini dapat disimpulkan bahwa DAU yang merupakan dana transfer yang bersifat block grant yang penggunaannya diserahkan kepada daerah sesuai prioritas daerah dan jumlah yang 
dialokasikan pun tidak terlalu besar tidak mendorong pemerintah daerah untuk meningkatkan pengungkapan transparansi informasi keuangannya. Jadi, hasil analisis ini menolak hipotesis bahwa DAU berpengaruh positif terhadap transparansi informasi keuangan daerah. Dengan demikian DAU tidak dapat dijadikan determinan transparansi informasi keuangan daerah melaluiegovernmentpemerintahdaerahdiSumateraSelatan.

\section{Dana Alokasi Khusus berpengaruh positif terhadap Transparansi Informasi Keuangan Daerah}

Hasil penelitian ini membuktikan bahwa dana alokasi khusus (DAK) tidak berpengaruh positif terhadap transparansi informasi keuangan daerah dengan DAK memiliki koefisien regresi 2,173 dan nilai signifikansi 0,721 dimana nilai tersebut lebih besar dari $0,10(\alpha=10 \%)$ dan 0,05 $(\alpha=5 \%)$. Hasil analisis tersebut tidak konsisten dengan Syafitri (2012) dan Liestiani (2008) yang menyatakan bahwa dana dana perimbangan, baik DAU, DAK, dan DBH memiliki pengaruh terhadap transparansi informasi keuangan daerah. Akan tetapi, hasil analisis ini konsisten dengan Jeckly dan Eka (2014) yang menyatakan dana perimbangan tidak memiliki pengaruh terhadap transparansi informasi keuangan daerah.

DAK (Undang-undang No. 33 Tahun 2004) merupakan dana yang bersumber dari APBN yang dialokasikan kepada daerah tertentu dengan tujuan untuk membantu mendanai kegiatan khusus yang merupakan urusan daerah dan sesuai dengan prioritas nasional. Seperti juga DAU, DAK bersifat special grant yang berarti penggunaannya ditentukan pemerintah pusat untuk mendanai pembangunan yang merupakan bagian dari belanja modal dan persentase DAK untuk belanja daerah yang kecil menjadi penyebab tidak signifikannya pengaruh DAK terhadap transparansi informasi keuangan daerah.

Dari hasil ini dapat disimpulkan bahwa DAK yang menunjukkan tingkat ketergantungan pemerintah daerah atas dana transfer semakin rendah sehingga menyebabkan pengungkapan PAD menjadi lebih prioritas utama pemerintah daerah dibandingkan dana perimbangan (termasuk DAK) dalam pengungkapan transparansi informasi keuangan daerah. Jadi, hasil analisis ini menolak hipotesis bahwa DAK berpengaruh positif terhadap transparansi informasi keuangan daerah. Dengan demikian DAK tidak dapat dijadikan determinan transparansi informasi keuangan daerah melaluie- governmentpemerintahdaerahdiSumateraSelatan. 


\section{DeterminanTransparansiInformasi}

\section{Rasio Pembiayaan Hutang berpengaruh positif terhadap Transparansi Informasi Keuangan Daerah}

Hasil penelitian ini membuktikan bahwa rasio pembiayaan hutang (RPH) tidak berpengaruh positif terhadap transparansi informasi keuangan daerah dengan RPH memiliki koefisien regresi 42,021 dan nilai signifikansi 0,166 dimana nilai tersebut lebih besar dari $0,10(\alpha=10 \%)$ dan 0,05 ( $\alpha=5 \%$ ). Hasil analisis tersebut tidak konsisten dengan Laswad dkk (2005) dan Rora (2010) yang menyatakan bahwa RPH memiliki pengaruh terhadap transparansi informasi keuangan daerah. Akan tetapi, hasil analisis ini konsisten dengan Medina (2012), Verawaty (2015), dan Nainggolan dan Purwanti (2016) serta Pitri dan Merina (2017) yang menyatakan RPH tidak memiliki pengaruh terhadap transparansi informasi keuangan daerah.

Berdasarkan pengujian yang telah dilakukan tidak membuktikan bahwa RPH berpengaruh terhadap pengungkapan transparansi informasi keuangan daerah. Kewajiban atau hutang merupakan transaksi yang timbul dari peristiwa masa lalu yang penyelesaiannya mengakibatkan aliran keluar sumber daya ekonomi pemerintah. Menurut Syafitri (2012), RPH merupakan proporsi yang menggambarkan besarnya hutang dari pihak eksternal dibandingkan dengan modal sendiri. Oleh karena itu, pengungkapan informasi keuangan melalui internet dapat memfasilitasi kreditur untuk mengawasi kinerja pemerintah daerah.

Dari hasil ini dapat disimpulkan bahwa pemerintah daerah yang rasio pembiayaannya lebih tinggi cenderung akan mengurangi akses ke informasi keuangan pada situs resminya. Hal ini dikarenakan penggunaan hutang yang lebih tinggi sebagai sumber pembiayaannya akan memberikan sinyal kinerja pemerintah daerah yang rendah. Oleh karena itu, pemerintah daerah yang rasio pembiayaannya lebih besar cenderung akan membatasi akses pengguna ke informasi keuangannya. Pembatasan akses dapat memberikan dampak bahwa pemerintah daerah kurang transparan atas informasi keuangan yang dimilikinya. Dengan demikian RPH tidak dapat dijadikan determinan transparansi informasi keuangan daerah. Jadi, hasil analisis ini menolak hipotesis bahwa RPH berpengaruh positif terhadap transparansi informasi keuangan daerah melalui e-government pemerintah daerah di Sumatera Selatan.

\section{PENUTUP}

\section{Simpulan}

Penelitian ini bertujuan untuk menguji determinan transparansi informasi keuangan daerah dalam APBD pemerintah daerah kabupaten/kota di Provinsi Sumatera Selatan pada Tahun 2017. Keempat determinan tersebut adalah pendapatan asli daerah, dana alokasi umum, dana alokasi khusus, rasio pembiayaan hutang. Berdasarkan hasil uji yang telah dilakukan, hanya pendapatan asli daerah (PAD) yang berpengaruh positif terhadap transparansi informasi keuangan daerah. PAD 
yang bersumber dari pajak dan retribusi yang dibayarkan oleh masyarakat telah bisa memotivasi pemerintah untuk dapat melakukan pengungkapan yang sesuai dengan Standar Akuntansi Pemerintahan. Masyarakat mulai menuntut hak informasi publik yaitu informasi keuangan. Peran pemerintah (agen) dan masyarakat (partisipan) telah dapat terlaksana dengan baik. Selain itu, tingkat ketergantungan pemerintah daerah atas dana transfer dirasa rendah sehingga menyebabkan pengungkapan PAD menjadi prioritas utama pemerintah daerah dalam pengungkapan transparansi informasi keuangan daerah.

\section{Saran}

Nilai Adjusted $R^{2}$ dari model yang diuji dalam penelitian ini sebesar 63,4\% maka ada 36,6\% variabel lain yang tidak digunakan dalam penelitian ini yang dapat mempengaruhi transparansi informasi keuangan daerah. Untuk penelitian-penelitian selanjutnya diharapkan dapat menggunakan data laporan keuangan pemerintah yang paling baru dan periode waktu yang lebih panjang sehingga lebih terlihat perkembangan tingkat pengungkapan transparansi informasi keuangan daerah. Selain itu, peneliti berikutnya bisa mencoba menganalisisnya secara deskriptif kualitatif sehingga melalui metode wawancara bisa ditemukan determinan yang mendorong atau menghambat transparansi informasi keuangan daerah.

\section{DAFTAR PUSTAKA}

Ardhani, P. (2011). Pengaruh Pertumbuhan Ekonomi, Pendapatan Asli Daerah, Dana Alokasi Umum, dan Dana Alokasi Khusus terhadap Pengalokasian Anggaran Belanja Modal (Studi pada Pemerintah Kabupaten/Kota di Jawa Tengah). Skripsi. Universitas Diponegoro, Semarang.

Craven, B., \& Marston, C. (1999). Financial Reporting on the Internet by Leading UK Companies.The European Accounting Review 8 (2), 321-333.

Fadzil, F.H., \&Nyoto, H. (2011). FiscalDecentralization after Implementation of Local Government Autonomy in Indonesia. World Review of Business Research 1 (2): 51-70.

Gore,A. (2004).TheEffectsofGAAPResolutionandBondMarketInteractiononLocal Government Disclosure.Journal of Accounting and PublicPolicy, 23: 23-52.

Hilmi, A.Z. (2010). Analisis Faktor-Faktor yang Mempengaruhi Tingkat Pengungkapan Laporan Keuangan Pemerintah Daerah Provinsi. Skripsi. Universitas Indonesia, Depok.

Jeckly, D.J., \& Eka, A.S. (2014). Pengaruh Pendapatan Asli Daerah, Dana Alokasi Umum, dan Belanja Modal pada Kelengkapan Pengungkapan Informasi Keuangan Daerah melalui Situs Resmi Pemerintah Provinsi. E-Jurnal Akuntansi Universitas Udayana, Denpasar. 
DeterminanTransparansiInformasi

Kravchuk, R.S., \& Voorhees, W.R. (1999). The New Governmental Financial Reporting Model under GASB No. 34: An Emphasis on Accountability. Public Budgeting and Finance, 21 (3): 1-30.

Laswad,F.,Fisher,R., \& Oyelere,P. (2005). Determinants of Voluntary Internet Financial Reporting byLocalGovernmentAuthorities.JournalofAccountingandPublicPolicy, 24:101-121.

Lesmana, S.I. (2010). Pengaruh Karakteristik Pemerintah terhadap Pengungkapan Laporan Keuangan Pemerintah Daerah di Indonesia. Skripsi. Universitas Sebelas Maret, Surakarta.

Liestiani, A. (2008). Pengungkapan LKPD Kabupaten/Kota di Indonesia untuk Tahun Anggaran 2006. Skripsi. Universitas Indonesia, Depok.

Mead, D.M. (2002). The Role of GASB 34 in the Citizen-Government Accountability Relationship. State and Local Government Review, 34 (1): 51-63.

Medina, F. (2012). Faktor-Faktor yang Mempengaruhi Transparansi Informasi Keuangan pada Situs Resmi Pemerintah Daerah di Indonesia. Skripsi. Universitas Indonesia, Depok.

Nainggolan, A.T., \& Purwanti, D. (2016). Analisis Faktor-Faktor yang Mempengaruhi Transparansi Informasi Keuangan Daerah via Website. STAN.

Pitri, D.P. \& Merina, C.I., 2017. Faktor-Faktor Penentu Transparansi Informasi Keuangan Daerah melalui E-Government Pemerintah Kabupaten/Kota di Provinsi Sumatera Selatan.Paper dipresentasikan pada Seminar Hasil Penelitian Fakultas Ekonomi dan Bisnis Universitas Bina Darma, 17 Maret 2017. Palembang.

Rora, P.S. (2010). Pengaruh Kinerja, Tingkat Ketergantungan dan Karakteristik Pemda terhadap Tingkat Pengungkapan Sukarela pada Situs Pemda. Skripsi. Universitas Indonesia, Depok.

Solihin, D. (2006).Mewujudkan Keuangan Negara yang Transparan, Partisipatif, dan Akuntabel. Paper dipresentasikan pada Diklatpim Tingkat IV Angkatan III Pusdiklat Pegawai BPK, 30 November 2006. Jakarta.

Styles, A.K., \& Tennyson, M. (2007). The Accessibility of Financial Reporting of US MunicipalitiesontheInternet.JournalofPublicBudgeting,AccountingandFinancial Management, 19:56-92.

Sugiyono(2012).MetodelogiPenelitianBisnis. Bandung: CV. Alfabet.

Syafitri, F. (2012). Analisis Pengaruh Karakteristik Pemerintah Daerah terhadap Tingkat Pengungkapan Laporan Keuangan. Skripsi. Universitas Indonesia, Depok.

Undang-Undang Nomor 32 Tahun 2004.Pemerintahan Daerah.

Undang-Undang Nomor 33 Tahun 2004. Perimbangan Keuangan Antara Pemerintah Pusat dan Pemerintah Daerah.

Verawaty, V. (2015).Determinan Aksesibilitas Internet Financial Reporting melalui E-Government Pemerintah Daerah di Indonesia. Paper dipresentasikan pada Seminar Nasional Simposium 
Nasional Akuntansi (SNA) XVIII, Universitas Sumatera Utara, 16-19 September 2015. Medan.

Verawaty, V. (2017). Accountability and InternetFinancialReporting of Local Government: An Indonesia Analysis. LAMBERT Academic Publishing, Germany. 